\title{
Initial data preparation for 3D modelling of heritage building
}

\author{
Miroslavas Pavlovskis ${ }^{1}$, Darius Migilinskas ${ }^{2}$, Vladislavas Kutut ${ }^{3}$, Jurgita Antucheviciene ${ }^{4}$ \\ Department of Construction Management and Real Estate, Faculty of Civil Engineering, \\ Vilnius Gediminas Technical University, Vilnius, Lithuania
}

E-mail: ${ }^{1}$ miroslavas.pavlovskis@vgtu.lt (corresponding author)

\begin{abstract}
Latterly problems of restoration of historic buildings have become especially important. Historical buildings require special attention while preserving their cultural and artistic values, so the three-dimensional digital model of the building can be used preparing their operational or renewal plans. The aim of the presented research is to analyze strengths, weaknesses, opportunities, and threats (SWOT) of preparation the initial data, heritage building 3D model development and parametric object databases creation. The object of the research is the Sapieha Palace built in Baroque style in 1689-1691 in the capital city of Lithuania. Applied research methods and tools - initial data collection by historical drawing analysis, manual measurement, photogrammetry methods, and "As-Built" 3D model creation. The results of the presented case study were analyzed by applying SWOT methodology as well as compared with the similar studies in the scientific literature. The research provides the basis for further construction heritage studies and analysis of possible object conversion issues.
\end{abstract}

Keywords: heritage building, 3D modelling, photogrammetry, “As-Built” 3D model, SWOT.

\section{Introduction}

In the modern conditions of commercialization, problems of reconstruction and restoration of historic buildings have become especially important. Monuments of the past and old buildings are rapidly disappearing due to real estate developers, whom destroying an existing building and building a new one is faster and cheaper than reconstructing and reviving the old one. This happens not only due to greed of new owners, but also due to complexity of conversion of construction heritage. However, in the era of modern technologies, the activity of restoration and reconstruction of heritage buildings is the area where modern digital technologies are the least ever applied (Volk, Stengel, \& Schultmann, 2014; Antón, Medjdoub, Shrahily, \& Moyano, 2018). Historical buildings require special attention while preserving their cultural and artistic values, so the three-dimensional digital model of the building can be used preparing operational or renewal plans and responding to a particular event (Osello, Lucibello, \& Morgagni, 2018). The aim of the presented research is to analyze strengths, weaknesses, opportunities, and threats of preparation the initial data, heritage building 3D model development and parametric object databases creation. In a future, the result of digitization can be applied for research, preservation, maintenance and refurbishment of heritage buildings. Archives of such databases of parametric objects allow increasing the speed and accuracy of the search to obtain reliable information about the object, and sets of their elements can be applied in the reconstruction or new construction all over the world.

The object of the research is the Sapieha Palace (in Lithuanian: Sapiegur rūmai; in Polish: Pałac Sapiehów w Wilnie). It is a High Baroque palace in Antakalnis district in Vilnius, Lithuania. The palace, ordered by Polish prince and Great Hetman of Lithuania Jan Kazimierz Sapieha the Younger, was built in Baroque style in 1689-1691. The palace was designed by Giovanni Pietro Perti and decorated with frescos by Michelangelo Palloni. The exterior of the palace was restored in 1843-1848 and in 1927-1928. The building is not in operation currently (Wikipedia, 2019).

Research methods and tools - initial data collection by historical drawing analysis, manual measurement, photogrammetry methods, and "As-Built" 3D model creation. The results of the current case study were analyzed as well as compared with the similar studies in the scientific literature (Pavlovskis, Antuchevičienè, \& Migilinskas, 2016; D'Amico \& Currà, 2017; Bruno \& Roncella, 2018). The SWOT analysis identified initial data preparation and 3D model development strengths, weaknesses, opportunities and threats. 


\section{Investigation of existing buildings: methods of data collection and processing}

Investigation of historical heritage and building heritage requires a lot of analytical work with archival and design documents, and old photographs. The result of digitization of this data - creation of databases of parametric objects, which include sets of volumetric models of architectural monuments and their elements, and provide general information about the object: its description, photos, cartographic information, etc. Archives of such databases would allow to increase search speed and accuracy and to obtain reliable information about the object.

Ilter and Ergen (2015) suggested to divide the research of existing buildings into the following stages:

- building data collection, "as-built" model development;

- modeling and management energy consumption;

- evaluation of a structure;

- access to and integration of technical information and data;

- exchange of information and information interaction.

Geometric and topographical information must be collected to create a BIM model for a building to be reconstructed. If a reliable data acquisition technique can provide a fully informative BIM model, information about the existing building can be used to manage documents or other tools (Volk et al., 2014; Anton et al., 2018).

In practice, this process begins with data collection and data processing, e.g. by laser scanning or photogrammetry, by using structural details and construction materials from historical and architectural books, databases of object elements are created. Correlation of parameter objects with laser scanning data allows the creation of the final virtual 3D model of a historic building. This detailed 3D model can provide most of the information about the object and the elements of the object, such as used building materials, operating cost reduction schedules, energy consumption, visualization, drawings, section planes, etc. (Logothetis, Delinasiou, \& Stylianidis, 2015).

When managing building heritage objects, it is important to ensure the availability of relevant and high quality data. One of the primary works is getting information "as built". These are the data on the geometry of the building, its architectural and structural properties, materials used, surrounding environment, engineering communications, etc. However, a usual problem with historical buildings is the lack of up-to-date information and project documentation. Also it is extremely important to avoid possible errors due to inadequate selection of measurement methodology to prevent further building management work. A particular method and technologies are determined by the size and peculiarities of the work.

\section{Collection of data from existing documents}

Data collection from drawings is the most commonly used way of modeling construction heritage objects. The collection of information begins with the examination of archival documents. Design of the building, drawings, section planes, materials used, documentation related to the repair works of the building or re-planning of the premises are analyzed. Coordinates, geometric dimensions of physical boundaries of land plot and structures, and other parameters are determined from the cadastral registration.

This method is understandable and acceptable for most people without the need for specific knowledge or expensive equipment, but it requires considerable time to search for relevant information and 3D modeling from 2D drawings. Often historical drawings do not correspond to reality, because the owners have reorganized the premises, annexed the building or demolished part of the building, they made an opening for a new window or immured an existing hole. Thus, it becomes necessary to supplement the 3D model with historical information. On the model, authentic and new elements are marked along with information about the construction time, materials and nowadays already non-existent elements.

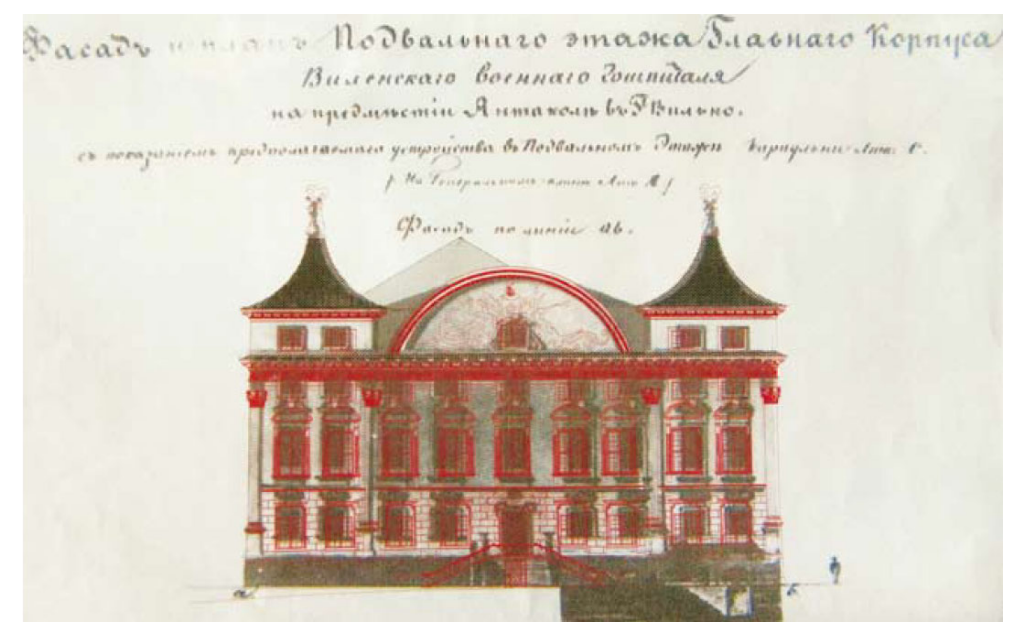

Figure 1. The main facade of Sapieha Palace, technical restoration Project, 1843 (Janonienè, 2010) 
In addition, the restoration of the authentic structure from the drawings results in a lack of dimensions and bindings. Often historical drawings and plans resemble art drawings in the modern sense (Figure 1). The reasons mentioned and the inaccuracies or errors in the drawings prolong the time of collection of data and require additional checks or measurements on the site. So this method can only be used in the initial stages of building heritage management.

\section{Manual Measurements}

Principle of the method - using different measuring tools, individual dimensions are fixed, which are later combined into one single digital drawing. The following are used for measurements: laser rangefinders, measuring tapes, rulers, protruders, plumbers, sleepers, levels, theodolites, and so on. During the measurements, geometry of existing buildings, position of elements and materials used are determined. Measurements are also made after the construction works are carried out in order to assess the quantities of work actually carried out, to check the quality of the works and materials and to approve the works executed by contractor (Dai \& Lu, 2010).

Depending on the size of the object and the time, measurements are usually made by at least 3 employees. The complete construction project includes drawings of all facades, floor and roof plans, section plans and drawings of non-repetitive elements. Measurements must also include information on the materials used in the building elements and the state of structures.

Before starting the measurements, sketch drawings are made by hand drawings or the CAD program, on which all the sizes received will be marked. Sketch drawing data requires preliminary measurements or existing drawings, photographs or schemes.

When the sketch is ready you can start measuring the work. We separate the dimensions. The drawing must be made in accordance with the drawing rules and on unified scale to avoid possible errors in the digitalization of information.

Weaknesses of the method are too high time expenditure, difficulties avoiding random human errors, difficult or impossible control of measurement results. Since linear measurements are made between the individual points, the form of object is evaluated in an idealized way - connecting the lines to the whole. Using this method, it is difficult to determine the exact geometry of building or the exact position of structural elements in space.

\section{Photogrammetry}

Photogrammetry is a science and technology for the accumulation of geometric data on objects measured from photographs. Principle of photogrammetry: 3D building surface modeling based on photographic images in which the object is mapped from different positions and points corresponding to the same physical point are automatically detected. The created 3D model can be incorporated into the environment, thus assessing the environmental impact of the designed building.

This method is widely used in construction and architecture for measurements in facade planning, 3D modeling, architectural monuments maintenance and management, etc. research and measurement.

The advantages of the method is time saving compared to traditional methods of measuring and documenting old buildings, which can take a long time, and also the method gives greater accuracy and it can identified building materials (Cepurnaite, Ustinovicius, \& Vaisnoras, 2017; Ustinovichius et al., 2018).

Shortcomings of the method is that in the design of BIM 3D model the photogrammetry method can only show the outer layer of elements of a building (Bruno, De Fino, \& Fatiguso, 2016), and BIM is composed of objects with an internal structure having parametric functions.

\section{Initial data preparation for 3D modelling: the case study of the Sapieha Palace}

Sapieha Palace (Sapiegų rūmai, in Lithuanian) is a High Baroque palace in Vilnius, Lithuania (Figure 2). It is the only surviving of several palaces formerly belonging to the Sapieha family in the city.

The palace was built in Baroque style in 1691-1697 in the place of former wooden mansion. The palace was designed by Giovanni Pietro Perti and decorated with frescos by Michelangelo Palloni. Originally, the palace had multi-floor arcades on its sides which were later built up to gain more space inside the building.

In 1809 the palace was acquired by the Russian government and restructured (according to Józef Poussier's design) into a military hospital in 1843. Much of the rich interior was destroyed throughout the 19th century. The exterior of the palace was restored only in 1927-1928 and the building housed University's Ophthalmology Institute until World War II. Since the war it has been used as military hospital again, later as civil hospital, and fell into disrepair. Today the complex houses Vilnius Tech Park, uniting international startups, tech companies, accelerators, incubators etc. While, the Sapieha Palace building itself is not in operation currently. Since 2012, the palace has been undergoing restoration, in an attempt to bring it as close as possible to its original Baroque appearance (Wikipedia, 2019). 


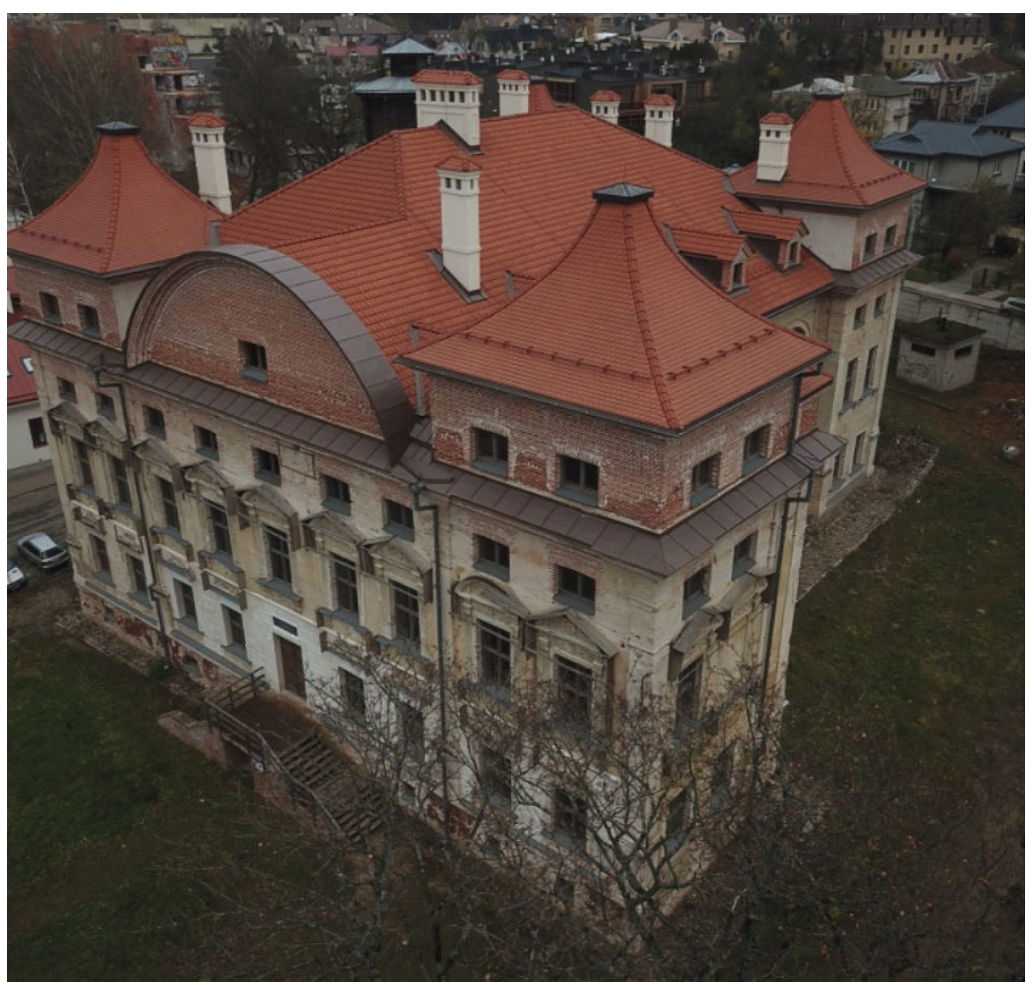

Figure 2. Sapieha Palace, Vilnius, Lithuania

\section{Initial data preparation}

Steps for initial data preparation, evaluation, digitalization and storage for 3D modelling of the Sapieha Palace presented in Figure 3.

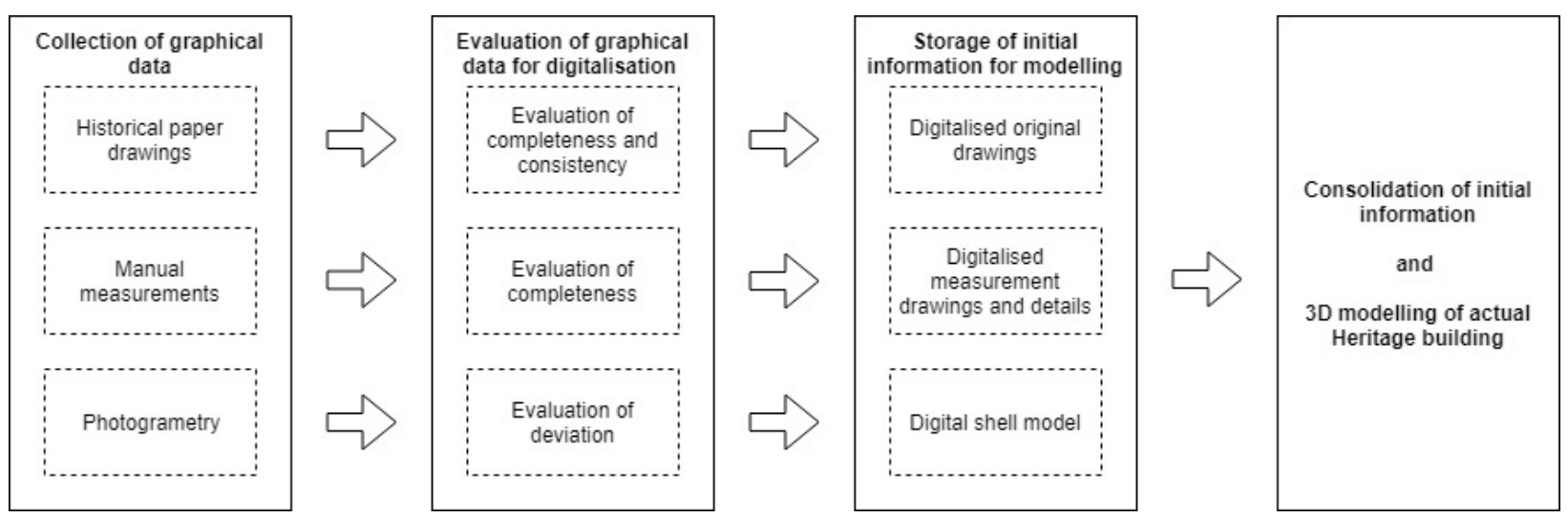

Figure 3. Data preparation levels for 3D modelling

For initial data preparation were used the DJI Mavic Pro drone with a DJI FC220 digital camera with 3-axis stabilization system and a navigation system for positioning. Photo processing was done using Bentley ContextCapture software. ContextCapture automatically transfers photos to $3 \mathrm{D}$ models, which means that the quality of the input data set has a major impact on the 3D model you are building.

To limit the hidden areas, the building was photographed in a circle on different levels. Next the aerial photographs were supplemented with terrestrial photographs. The reconstruction process starts with loading of photos and aerotriangulation for image processing. Aerotriangulation is the determination of coordinates of relief points based on aerial photography (Figure 4). 


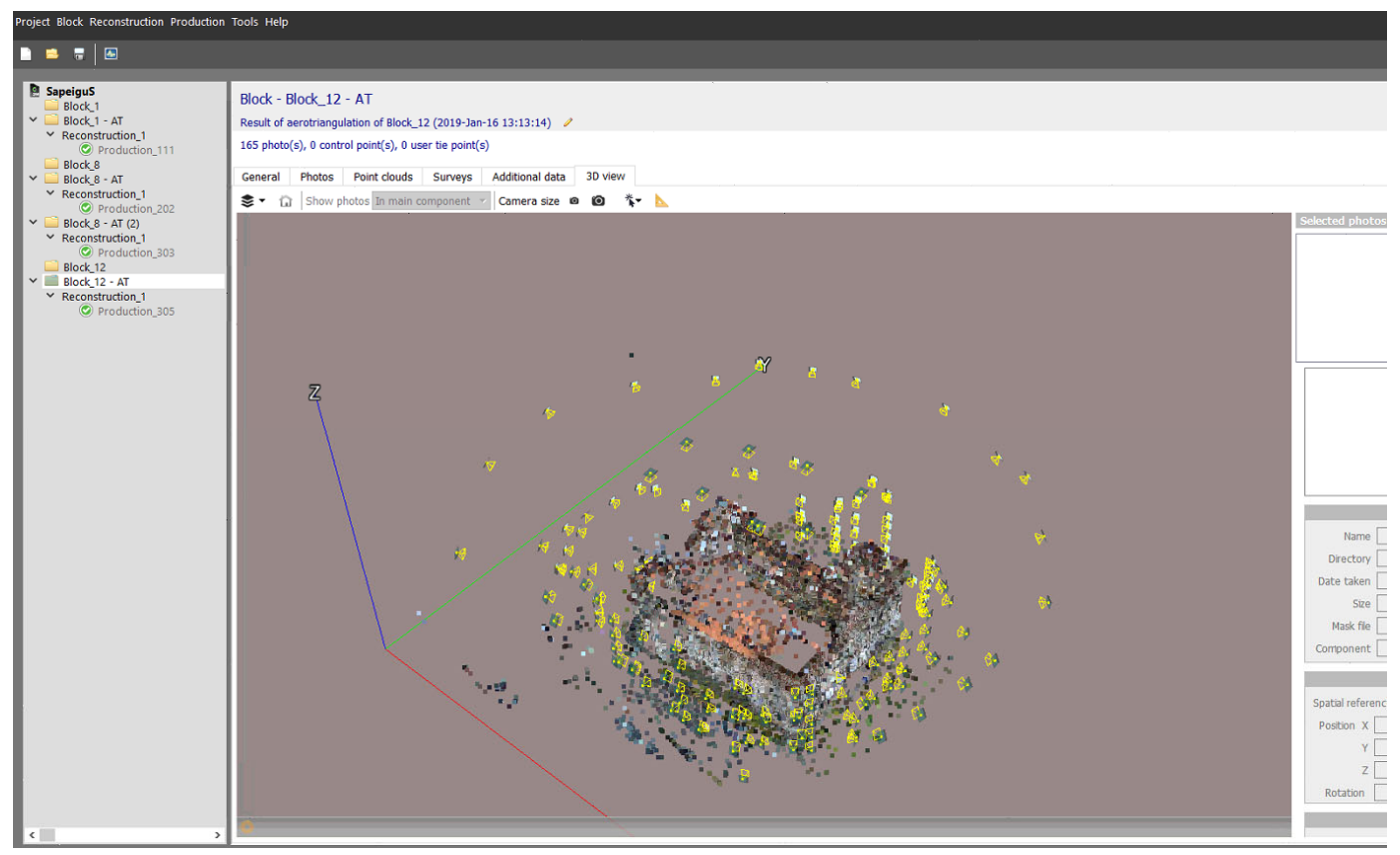

Figure 4. Completed aerotriangulation 3D dataset

Next we submit the job for reconstruction (the process where the photos are processed into the 3D mesh and/or point-cloud.) The reconstruction process uses the aerotriangulation information to process the images and create a 3D dataset. That data is then presented in a user selected format such as a $3 \mathrm{D}$ mesh, point-cloud or orthomosaic raster images.

3D model of the data represented as a mesh (Figure 5) and can then be used in several Bentley products either as building model reference data. This lends itself uses for reconstruction or facility management.

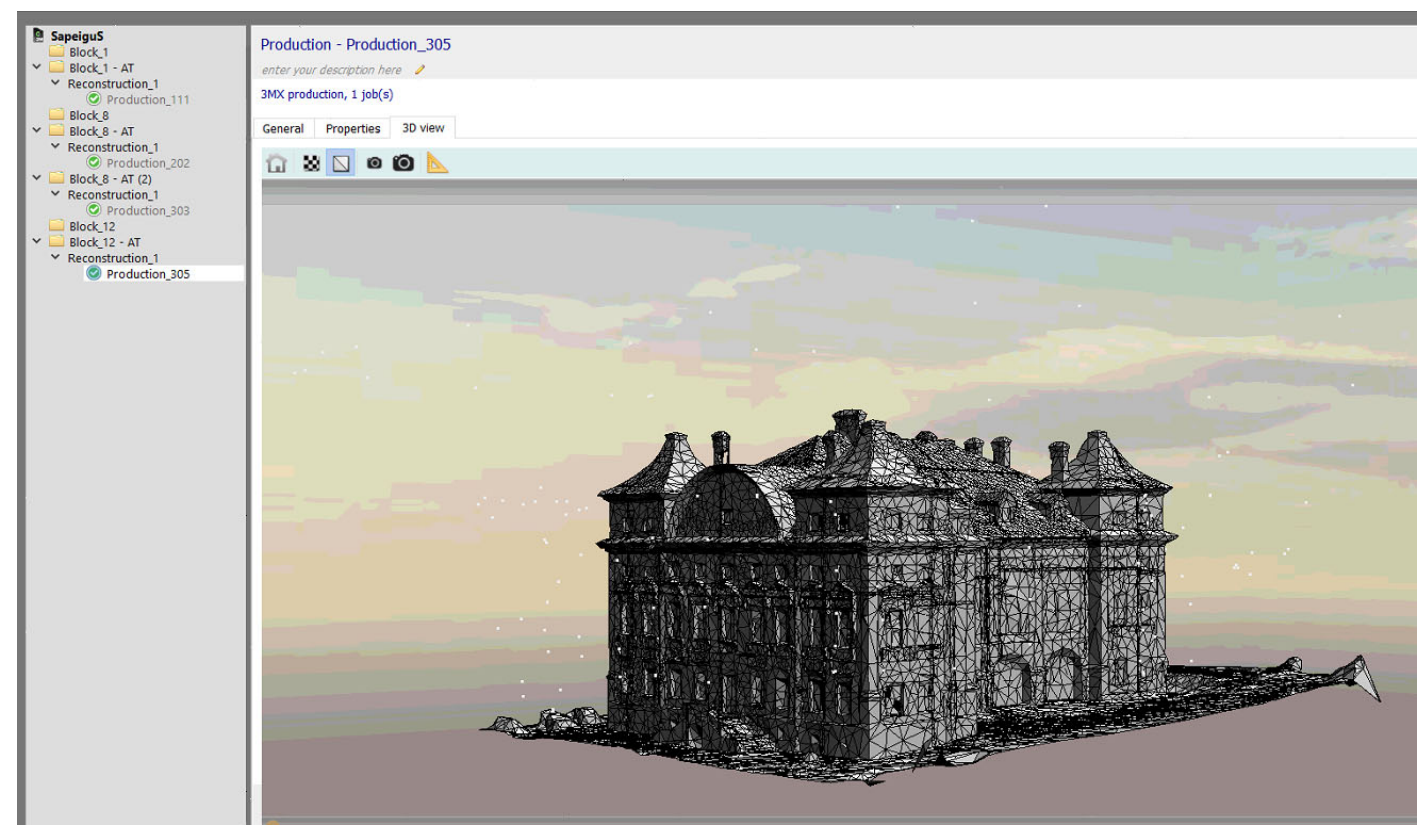

Figure 5. 3D model of the data represented as a mesh

Aerotriangulation quality overview: quality measures on tie points

Number of tie points is detected by ContextCapture in the photo dataset. A tie point is a 3D point that was identified in two or more images by corresponding 2D keypoints.

Results of quality measures on tie points in the case study of the Sapieha Palace are presented in Table 1 and described below. 
Table 1. Quality Measures on Tie Points

\begin{tabular}{|c|c|c|c|c|c|}
\hline \multicolumn{7}{|c|}{ Generated Tie Points } \\
\hline $\begin{array}{c}\text { Number of } \\
\text { Points }\end{array}$ & $\begin{array}{c}\text { Median Number of } \\
\text { Photos per Point }\end{array}$ & $\begin{array}{c}\text { Median Number of } \\
\text { Points per Photo }\end{array}$ & $\begin{array}{c}\text { Median } \\
\text { Reprojection } \\
\text { Error (pixels) }\end{array}$ & $\begin{array}{c}\text { RMS of } \\
\text { Reprojection } \\
\text { Error (pixels) }\end{array}$ & $\begin{array}{c}\text { RMS of Distances to } \\
\text { Rays (meters) }\end{array}$ \\
\hline 27560 & 3 & 606 & 0.58 & 0.79 & 0.00243 \\
\hline
\end{tabular}

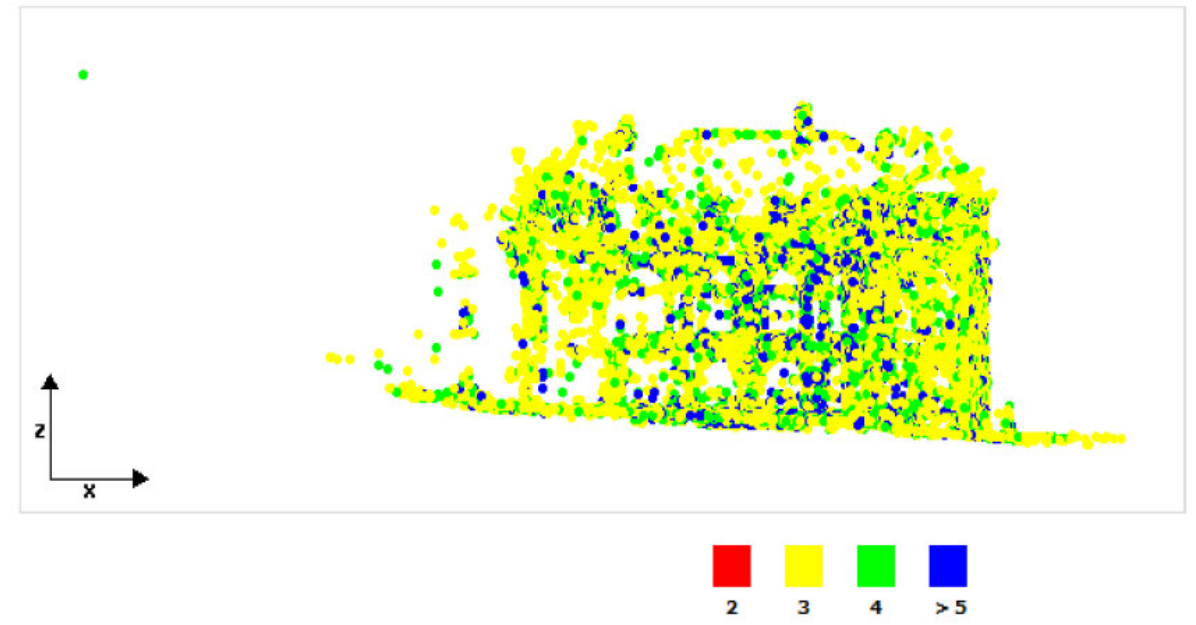

Figure 6. Number of Observations per Tie Point: Front view (XZ plane)

Number of observations per tie point: front view (XZ plane) displays all the tie points with colors representing the number of photos that have been used to define each point (Figure 6). The minimum number of photos per tie point is 3 and the maximum number of photos per tie point is 16 . The average number of photos observing at a tie point is 4 .

Reprojection error value in pixels represents the root mean square (RMS) of reprojection errors computed for each generated tie point, and it is presented in Table 2. Reprojection errors per tie point: front view (XZ plane) displays all the tie points with colors representing the reprojection error in pixels (Figure 7). The minimum RMS of reprojection error is 0.02 pixels and the maximum RMS of reprojection error is 1.81 pixels. The average RMS of reprojection error is 0.73 pixels that shows high accuracy level of measures.

Table 2. Value rules of reprojection errors

\begin{tabular}{|c|c|}
\hline $\begin{array}{c}\text { RMS of Reprojection Errors } \\
\text { (pixels) }\end{array}$ & Accuracy Level \\
\hline$<1$ pixel & High \\
\hline (1 pixel, 3pixels) & Medium \\
\hline$>3$ pixels & Low \\
\hline
\end{tabular}

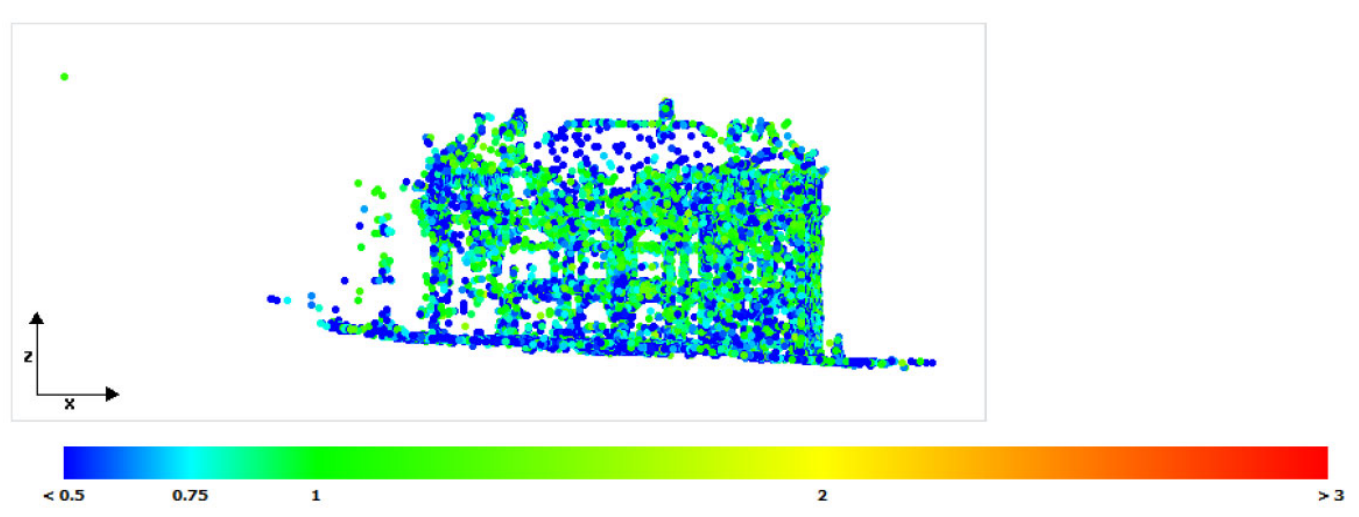

Figure 7. Reprojection errors per tie point: front view (XZ plane) 


\section{SWOT analysis}

The results of the current case study were analyzed as well as compared with the similar studies in the scientific literature (Pavlovskis et al., 2016; D’Amico \& Currà, 2017; Bruno \& Roncella, 2018). The SWOT analysis identified several strenghts, weaknesses, opportunities and threats during initial data preparation and 3D model development (Table 2).

Table 2. SWOT analysis

\begin{tabular}{|c|c|}
\hline $\begin{array}{l}\text { Strengths } \\
\text { The selected methodology has proven its effectiveness and } \\
\text { made it possible to overcome the difficulties associated with } \\
\text { studying the analyzed object; } \\
\text { Analysis of scanning results and more observation point } \\
\text { increase the accuracy level; } \\
\text { Similar methodology in the future is applicable to other objects } \\
\text { of the construction heritage. }\end{array}$ & $\begin{array}{l}\text { Weaknesses } \\
\text { Data collection technologies allow to get extremely detailed } \\
\text { data, but the added value of small element modelling does } \\
\text { not fullfill the time and cost ratio requirement associated } \\
\text { with data collection and detailed modeling; } \\
\text { Data collection from limited surroundings and complicated } \\
\text { objects leads to the low level of accuracy and high level of } \\
\text { ambiguity. }\end{array}$ \\
\hline $\begin{array}{l}\text { Opportunities } \\
\text { By investigating complex construction heritage objects and } \\
\text { their direct and indirect link to the environment, maximum } \\
\text { efficiency would be achieved by using all of the above methods } \\
\text { together, providing integrated data collection and } \\
\text { comprehensive object analysis; } \\
\text { Methodology can be improved to reach even better equipment, } \\
\text { data accuracy and information management based on the } \\
\text { appropriate time and cost ration. }\end{array}$ & $\begin{array}{l}\text { Threats } \\
\text { Ambiguity results of the graphical analysis on curved } \\
\text { surfaces influence total results; } \\
\text { Bad model quality in the ,grey areas“, results of scanning } \\
\text { glass and influence of reflections; } \\
\text { Need improved solutions for limited space around the object } \\
\text { and extremely high or low details. }\end{array}$ \\
\hline
\end{tabular}

\section{Conclusions}

Historical buildings require special attention while preserving their cultural and artistic values, so the three-dimensional digital model of the building can be used preparing their operational or renewal plans.

The authors apply research methods and tools as initial data collection by historical drawing analysis, manual measurement, photogrammetry methods, and "As-Built" 3D model creation. The object of the research is the Sapieha Palace built in Baroque style in 1689-1691 in the capital city of Lithuania.

Quality measures on tie points of the 3D model show high accuracy level of measures. The average RMS of reprojection error is 0.73 pixels that means high reprojection accuracy level. Such accuracy level of measures is sufficient for further construction heritage research in terms of its conversion possibilities.

The results of the current case study considerably coincide with similar studies in the scientific literature. Such drawbacks and threats arise regardless of which research object is selected or which software is used. This indicates the importance of the problem and the direction of future research.

This research provides the basis for further construction heritage research and analysis of possible object conversion issues.

\section{References}

Antón, D., Medjdoub, B., Shrahily, R., \& Moyano, J. (2018). Accuracy evaluation of the semi-automatic 3D modeling for historical building information models. International Journal of Architectural Heritage, 12(5), 790-805. https://doi.org/10.1080/15583058.2017.1415391

Bruno, N., \& Roncella, R. (2018). A restoration oriented HBIM system for cultural heritage documentation: the case study of Parma Cathedral. In The International Archives of the Photogrammetry, Remote Sensing and Spatial Information Sciences (vol. XLII-2, pp.171-178). ISPRS TC II Mid-term Symposium “Towards Photogrammetry 2020", 4-7 June 2018. Riva del Garda, Italy. https://doi.org/10.5194/isprs-archives-XLII-2-171-2018

Bruno, S., De Fino, M., \& Fatiguso, F. (2016). HBIM-aided refurbishment process of Cultural Heritage. In A. Ciribini, G. Alaimo, P. Capone, B. Daniotti, G. Dell'Osso, M. Nicolella, (Eds.), ISTeA-Back to 4.0: Rethinking the digital construction industry (pp. 60-69).

Cepurnaite, J., Ustinovicius, L., \& Vaisnoras, M. (2017). Modernization with BIM technology through scanning building information. Procedia Engineering, 208, 8-13. https://doi.org/10.1016/j.proeng.2017.11.014

Dai, F., \& Lu, M. (2010). Assessing the accuracy of applying photogrammetry to take geometric measurements on building products. Journal of Construction Engineering and Management, 136(2), 242-250. https://doi.org/10.1061/(ASCE)CO.1943-7862.0000114

D'Amico, A., \& Curra, E. (2017). From TSL survey to HBIM, issues on survey and information modeling implementation for the built heritage - The case study of the Temple di Bacco Ravello. In A. Fioravanti, S. Cursi, S. Elahmar, S. Gargaro, 
G. Loffreda, G. Novembri, A. Trento (Eds.), ShoCK - Sharing Computational Knowledge - Proceedings of the $35^{\text {th }}$ eCAADe Conference, 20-22 September 2017 (vol. 2, pp. 39-48). Sapienza University of Rome, Rome, Italy.

Ilter D., \& Ergen, E. (2015). BIM for building refurbishment and maintenance: Current status and research directions. Structural Survey, 33(3), 228-256. https://doi.org/10.1108/SS-02-2015-0008

Janonienè, R. (2010). Sapieha Palace in Vilnius: development and interior decoration [Sapiegų rūmai Vilniuje: raida ir interjero puošyba]. Acta Academiae Artium Vilnensis, 57, 2015-236 (in Lithuanian).

Logothetis, S., Delinasiou, A., \& Stylianidis, E. (2015). Building information modelling for cultural heritage: A review. ISPRS Annals of the Photogrammetry, Remote Sensing and Spatial Information Sciences, 2(5), 177-183. https://doi.org/10.5194/isprsannals-II-5-W3-177-2015

Osello, A., Lucibello, G., \& Morgagni, F. (2018). HBIM and virtual tools: a new chance to preserve architectural heritage. Buildings, 8(1), 12. https://doi.org/10.3390/buildings 8010012

Pavlovskis, M., Antuchevičienè, J., \& Migilinskas, D. (2016). Application of MCDM and BIM for evaluation of asset redevelopment solutions. Studies in Informatics and Control, 25(3), 293-302. https://doi.org/10.24846/v25i3y201603

Ustinovichius, L., Popov, V., Cepurnaite, J., Vilutienė, T., Samofalov, M., \& Miedziałowski, C. (2018). BIM-based process management model for building design and refurbishment. Archives of Civil and Mechanical Engineering, 18(4), 1136-1149. https://doi.org/10.1016/j.acme.2018.02.004

Volk, R., Stengel, J., \& Schultmann, F. (2014). Building Information Models (BIM) for existing buildings - literature review and future needs. Automation in Construction, 38, 109-127. https://doi.org/10.1016/j.autcon.2013.10.023

Wikipedia. The free encyclopedia. (2019). Sapieha Palace, Vilnius. Retrieved from https://en.wikipedia.org/wiki/Sapieha_Palace, Vilnius 